\title{
Developments in Christianity in Southwestern Nigeria Immediately after the First World War
}

Ogunrinade Adewale O. (Ph.D.)

E.Mail: walesoft@yahoo.com Phone: +2348035522497

\author{
Ogbole Friday Abu (Ph.D. Candidate)
}

E-Mail: foabu@yahoo.com Phone: +2348036382200

Department of Religious Studies,

Faculty of Arts and Social Sciences Gombe State University, Gombe, Nigeria

Doi:10.5901/mjss.2013.v4n6p619

\begin{abstract}
Immediately after the First World War, the effect of such a massive war was already biting hard on the world populace. Nigeria as a nation shared in the problem through diseases and economic depression. This paper identifies the existing major Christian Mission organizations in Southwestern Nigeria before 1918. Their names and dates of arrival are as follows: the Wesleyan Missionary Society (September 1842), Church Missionary Society (December 1842), the Baptist Mission (February 1849), and the Catholic Mission (as from 1860). It further examines the advent of Nationalism in Christianity in Southwestern Nigeria, the occasion for it and the foremost nationalistic churches founded between the late $19^{\text {th }}$ and the Early $20^{\text {th }}$ Centuries. It also observes the events that happened in Southwester Nigeria vis-à-vis the aftermath of the war on Christianity and Christians in Southwestern Nigeria and how they responded to it. Some relevant literatures were consulted to dig out the facts pertaining to the study. Logical reasoning and historical method were used in treating findings and in reconciling the information and evidence in the literature. After the war, there was massive repatriation of the foreign missionary expatriates because of insufficient fund to maintain them and outbreak of diseases (prominent was the Bubonic Epidemic in Southwestern Nigeria) which resulted in the death of many people. Gates of churches founded by the missionaries were closed since they felt Africans could not administer churches independently. African Christians were grossly abandoned to their fates. Christians gathered at the gates of the secured churches to pray and fast for a divine solution to the problems. A praying society thereafter emerged. The economic depression at the time was interpreted as the aftermath of the sins of man. Solution to the Bubonic plague was found through Cura Divina (Divine Cure) by the drinking of consecrated water. The Precious Stone Society which later blossomed into the Faith Tabernacle Nigeria disproved the earlier assertion of the foreign missionaries that Africans could not oversee churches. African personnel were important in the founding of a self sustaining, self funding and self governing Christianity that addresses the myriad African existential challenges.
\end{abstract}

\section{Introduction}

The World War I was described as the military conflict that ensued from August 1914 to November 1918 which involved many countries of the world such as countries from Europe and United States. The countries that partook included Russia Empire, France, British Empire, Italy, United States, Romania, Serbia, Belgium, Greece, Portugal and Montenegro under the Allied Powers. Under the Central Powers, countries that participated included Germany, AustriaHungary, Othoman Empire and Bulgaria. Out of the 65 Million men mobilized, more than 10 Million were killed while more than 20 Million were wounded. As from 1918, the effect of the war was already hitting every part of the world in terms of hunger, economic depression, insecurity, diseases and epidemics that ravaged the peoples of the world and instability in governance throughout the world especially in the colonized territories (World War I. 2010, Keylor, William R. 2009). Though Nigeria could be regarded as not actively participating in the war, it shared in the problems associated with it. Because the British Empire actively participated in the war, attention given to its colonies in relation to funding and personnel dwindled. Nigeria was adversely hit by this development being a colony of the empire. How did the fragile 
Christianity that existed then survive the situation and how was the religion able to interpret and solve some of the problem brought about by the war? These would be the concerns of this paper.

\section{Existing Christian Mission Organisations in Southwestern Nigeria Before 1918}

There is no means of discussing the existing missionary organizations that penetrated Southwestern Nigeria before 1918 without making recourse to Sierra Leone. As a result of the intertribal wars that became popular in the Early Nineteenth Century among the Yoruba people in Yoruba land, many men were who were either taken captive by the victors of such wars or captured in their homes were transported as slaves by ship to Europe and America. These people ended up serving their masters in their homes and farms. As a result of these wars, many men were reduced to what E.A. Ayandele refers to as the "living tool" (E.A. Ayandele, 1966). Even when Britain passed a bill known as the "The Slave Trade Abolition Act" and another referred to as the Emancipation Act, slave traders were reluctant to stop the trade because it was a lucrative business.

Sierra Leone is significant because when the slaves were repatriated from their land of servitude, it was their next port of destination where Britain chose that they be settled. A large group of the returned slaves were the Yoruba otherwise known then as the Akus derived from the prefix of Yoruba greetings Eku. Modupe Oduyoye acclaimed that the Yoruba ethnic group was not only the largest of the freed slaves in Sierra Leone but also the most cohesive (M. Oduyoye. 1978). Because the language was well spoken, it was studied and reduced to writing by the missionaries operating among them. The first African black bishop (Bishop Samuel Ajayi Crowther) who happened to be a liberated slave was from the Yoruba tribe. He was instrumental in translating the Bible from English to Yoruba. He wrote $A$ Grammar and Dictionary of the Yoruba Language, in 1843, Translations of Luke, Acts, James and Peter in 1851, and A Vocabulary of the Yoruba Language in 1852. Also, he officiated and even preached in the first Christian service conducted in Yoruba Language in Sierra Leone on January 3, 1844. Extract of his sermon appears below:

A large number of Africans crowded hither to hear the words of prayer and praise for the first time in their own tongue in an English church. "Although it was my native language with which I am well acquainted, yet on this occasion it appeared as if I were a babe, just learning to utter my mother-tongue. The work in which I was engaged, the place where I stood, and the congregation before me, were altogether so new and strange, that the whole proceeding seemed to myself like a dream. ..At the conclusion of the blessing, the whole church rang with "ke oh sheh"- so be it, so let it be!" (Oduyoye, M. 1978).

We shall briefly identify four missionary societies that entered the Southwestern Nigeria in succession. They are the Wesleyan Missionary Society, Church Missionary Society, Baptist Missionary Society and the Catholic Mission. The Wesleyan Missionary Society first made its entry into Nigeria through Badagry as from 1842. This incidence came through the first liberated emigrants to Badagry by name James Ferguson who happened to be a Wesleyan convert. His stay in Badagry without any missionary ministering unto the converts there was not spiritually fulfilling so he wrote to the Wesleyan Missionary Society for a missionary. Thomas Birch Freeman was sent from cape Coast. He was the first Methodist Missionary to come to Nigeria. By the time of his arrival, about three hundred former slaves were already settled for about two years in Badagry some of whom had already started to trade in palm oil between Badagry and Freetown.

The next missionary society to enter Southwestern Nigeria was the Church Missionary Society who sent Rev. Henry Townsend. Townsend came in 1842 through a slave ship (The Wilberforce) bought by a Negro proprietor. He was just a brave missionary who entered the missionary voyage when others were backing out because of the numerous missionary challenges that the mission was bedeviled with especially to West Africa. When he landed in Badagry on $17^{\text {th }}$ December 1842, he met was welcomed by Thomas Birch Freeman and the duo worshipped together in the Methodist Church at Badagry on Christmas day before Townsend travelled to Abeokuta on the $29^{\text {th }}$ of December.

The Baptist Mission was the third missionary society to come to Southwestern Nigeria. This mission could be traced to the expedition of Thomas Bowen, Harvey Goodale and Robert F. Hill. These missionary were initially assigned and sent to Central Africa and specifically the Northern Nigeria on the $22^{\text {nd }}$ of February, 1849. On their way, they made a stop in Liberia in order to become accustomed to the climate of the region they were going. While they were acclimatizing, Harvey Goodale fell sick and died in Sama country. Thomas Bowen continued his journey to Badagry. As he was planning of moving to Ighoho from Lagos, the war in Yoruba region prevented him from assessing the Igboho road which was closed down. He stayed in Abeokuta which appeared a safe place. While in Abeokuta, he engaged in the study of Yoruba language and Vocabulary wherein he published a book on Yoruba grammar and its vocabulary. 
The Catholic Missionary organization entered the Southwestern Nigeria through Dahomey as from 1860. The establishment of the Society of the African Mission for the planting of Christianity in Nigeria initially wanted to Christianize Sierra Leone around 1860 but the attempt was futile. This society then moved to Dahomey where they were successful. Father Borghero was in charge ably assisted by two other missionaries. Father Borghero was as Italian Roman Catholic father who stationed in Whydal in Dahomey. In 1862, he visited Lagos and met with some catholic freed slaves from Brazil and also some Brazilians who were baptized members of the Roman Catholic Church living in Lagos. Te enthusiasm and dedication of these people made him to establish a mission station in Lagos and sent a Catechist named Padre Antonio, a freed slave from Sao Tome to head the station (Agbeti, K.J. 1986). While the Catechist was in Lagos, he successfully commenced, taught and baptized adherents and converts into the Catholic Mission. This was the beginning of the mission in Southwestern Nigeria. Other missionary societies came after the four aforementioned societies but they shall not be the concern of this work.

\section{Development of Nationalism in Christianity in Southwestern Nigeria}

Nationalism in politics is simply described as the desire to achieve political independence, especially in a country under foreign control or among people who share different identity and culture without any state of their own. In Christianity, nationalism comes in when the African Christians felt that the foreign missionaries had taken grip of every facet of church planting and administration in Africa. It is further interpreted as reactions exhibited by the natives in their own land concerning the "disgusting" attitudes of the foreign missionary personnel and government about the people's valued customs, culture and worldviews. A typical example of such disgust is manifested in the above expression of a Capuchin missionary in Congo though this happened long before the advent on Nationalism in the late $19^{\text {th }}$ and early $20^{\text {th }}$ Centuries in Nigeria. The expression below reflects how the foreign missionaries grossly disregarded and scorned the culture and religion of the Africans which gave rise to Nationalism: On my way, I found numbers of idols, which I threw into the fire. The owner of these idols... seemed very annoyed. To calm him down by humiliating him, I let him know that if he persisted in anger, I should see that he himself \{is\} burnt with the idol (A. Hasting, 1966).

In the Late $19^{\text {th }}$ and Early $20^{\text {th }}$ Century, Nationalism was known as Ethiopianism. Origin of Ethiopianism was a subSaharan African religious movement which consisted of earlier rousing towards religious and political freedom in the modern colonial period. Though this movement started in 1880s when South African mission workers started to form independent all-African churches like the Tembu Tribal Church (1884) and Church of Africa (1889) (Ethiopianism. 2010 Encyclopædia Britannica). Nigeria's version of Ethiopianism started in 1888 in Southwestern Nigeria. These are the churches that set the pace for the founding of African indigenous churches. The churches thus established among the Yoruba as from 1888 such as The Native Baptist Church (1888), The United Native African Church (1891), The African Church Bethel (1901) and The United African Methodist Church (Eleja) (1917) represented the first set of Ethiopian churches founded in Nigeria. All these churches were founded because they desired African identity, leadership and expression in church governance.

The Native Baptist Church broke away from the Southern (American) Baptist Church because of the way the presiding American pastor of the church Rev. David dismissed the indigenous Catechist of the church Rev. Ladejo Stone without carrying the church along. When he was confronted, he showed no remorse but threatened the congregation the more with excommunication if anyone acted the way Rev. Stone acted. This made the majority of the congregation to secede from the American Baptist Church to establish the Native Baptist Church. The United Native African Church unlike the Native Baptist Church did not break away from any mission assembly. On contrary, those who constituted the church gathered from different churches. The founding of this church was spurred through the lecture presented by Wilmot Blyden in December 1890 titled The Return of the Exile and the West African Church. In the paper, he claimed that there would never be a firm Christianity in Africa as long as the foreign missionaries continued to dictate the affairs of the church. He asked African Christians to be united and do away with denominationalism. As a result of this, a nondenominational congregation was suggested to be founded but due to financial constraint, this plan was shelved. William Cole who was so much interested in this plan renewed it, so the United Native African Church was established in 1891 (Ayégbóyìn, D. and İshola S. A. 1997).

The African Church Bethel was the third nationalistic church to be founded in southwestern Nigeria in 1901. This occurred ten years after the inauguration of the United Native African Church which we discussed previously. African Church Bethel was a product of a major secession in the Anglican Church of St. Paul's Breadfruit in Lagos under the leadership of Rev. James Johnson. When the splintering eventually occurred, it did not astonish many enthusiastic observers who had monitored the issue from the religious and political situations of the time. The secession was 
premeditated upon an earlier agitation by many Africans who had protested the deliberate attempt of the Church Missionary Society to impose European culture and also destroy the so much valued African culture of the people. They termed this as being under ecclesiastical and political bondage of the missionaries. The direct origin of the secession was the maltreatment of Rev. James Johnson the native reverend of the church by Bishop Tugwell and the unserious manner through which the Bishop handled the information he had about a possible disintegration in the church (Webster, J.B. 1964, Oshun, C.O. 1981). When he learnt that there was an imminent break, he underrated the intelligence of the Africans to administer a church. The event led to 600 members that constituted about two-third of the membership of the church withdrawing from the church to form the new church in 1901.

The United African Methodist Church Eleja was the fourth nationalistic church among the Yoruba people. Its founding was premised upon Rev. D.H. Loko's opposition to polygamy and the demonstration of this by threatening to indict and expel ten well-known polygamists. He carried this out through the support of Rev. G.O. Griffin who was the chairman of the Lagos District. He called out the names of these ten polygamists and pronounced them expelled from the church. Immediately, fifty five self confessed polygamists associated with these ten and asked that they too be judged. The reverend instantly expelled them as well making a total of sixty-five polygamists expelled at once. These people decided to establish a separate church ungoverned and uncontrolled by any foreign missionary body to serve God "in spirit and in truth". Just a month after the expulsion, The United African Methodist Church was founded and its first service held on the $28^{\text {th }}$ of December, 1917. The appellation Eleja (fishermen or fish mongers) was added first to signify that Christians are fishers of men and second when they relocated the church to a building adjoining the fish market (Ayégbóyìn, D. and İshola, S. A. 1997).

\section{Post War Effect}

Immediately after the First World War, there were a lot of human sufferings. The casualty of war was enormous. About $8,500,000$ soldiers died due to wounds and/or disease while a lot more were declared missing. Close to 21 Million soldiers were wounded. The extent of the physical destruction and the geographical land mass was huge (World War I. 2010 Encyclopædia Britannica). The standards of living of many people dropped seriously abruptly. The adverse effect of the war reduced the rate of employment. The war also led to a lot of revolution and unrest. The end of the war embittered many people because many empires collapsed and the losers of the war had to pay reparations while the winners expanded in land acquisition (Keylor, William R. 2009 "World War I).

The impact of the war in Africa was profound. Since there was the need to send more people to the war front, many colonial expatriates working in Africa were either recalled or went home voluntarily. By this they left the management of the sundry colonial outfits they were previously manning in the hands of the Africans. Such outfits included administrative duties and mercantile positions throughout the European colonies. This translated into shortage of manpower and competency. There was also severe economic cost. There was reduction in consumer goods leading to inflation in such areas as Madagascar, Senegal and South Africa and massive demands for increase in wages from the colonial administrations especially in South Africa resulted. In certain areas of the East and Central Africa, famine struck and later epidemics of great magnitude decimated the African people, so many millions of people died that in some places, as much as six percent of the population died. Though, it is generally believed that Africa was only a sideshow of the world war, the real truth lies in the fact that the continent participated fully through the consequences it suffered from the war.

Politically, Africa experienced a succession of insurrections against colonial rule. There were the gatherings of many rebel camps against their colonial masters in places as Morocco against the French rule, Cyrenaica on the north coast against the Italian rule and Central Sahara against the British and French rulers (Keylor, William R. 2009 "World War I). In Southwestern Nigeria, the postwar effect culminated in epidemics and economic depression. Many European expatriates left for their countries so as not to be caught with the unpalatable effects of the war. Financial supports from the British Empire to its colonies were not forthcoming. As a result of this, many businesses owned by them had to fold up. The church administration was not left out of this problem. Many churches had to close since the foreign missionaries administering those churches had been recalled home. While they were going, it was possible that they collectively agreed to secure the gates of their churches and leave with the keys. One example which gave us this notion was the case of St. Savior's Anglican Church, ljebu-Ode where the gates of the church were put under lock and key. The missionaries felt that Africans could not administer churches on their own without supports from them. By this attitude, they underrated the consciousness of the Africans about their ability to found and administer churches successfully. At this junction, we would not know whether this order came from the British Empire or it was carried out at the discretion of 
the individual church administrator. However, C.O. Oshun claimed that the churches were closed through the directive of the government (Oshun, C.O. 1981).

\section{Occasion for the Precious Stone Society and Controversies on Cura Divina}

Before the origin of the Aladura churches, there were the activities of itinerant prophets who had conducted individualistic preaching and evangelism throughout Nigeria. One of them was Garrick Sokari Braide who moved around the Niger Delta Pastorate and the Southern Zone of Owerri District from 1915 till November 1918 when he died. There were also the itinerant ministries of Egunjobi who was a former hunter and Babamuboni (formerly Ifamuboni) who was a catechist in his village. The latter two were Yoruba. All the three itinerant prophets were from the Anglican Church before they started their itinerary.

Due to the effect of the First World War, many problems needed to be solved. There were many of these problems that the government could not solve. One of them was the outburst of diseases and epidemics. Since most of the hospitals had been deserted by doctors and nurses from the British Empire that colonized Nigeria, many of the post war ailments could not be contained. The local people therefore resigned to faith.

As this episode was going on, a man named Daddy Alli the sexton of St. Saviour's Church Ijèbú-Òde claimed that he had a dream. The vicar-in-charge of the church Rev. S.J Gansallo was rather careless about the dream. Therefore, he conscripted four other brethrens who made up the foundation members of the Precious Stone Society. Daddy Alli dreamt that the church was fragmented into two unequal halves. One half was brightly lit while the other half was in darkness. The half in darkness was bigger than the half in light. This dream was interpreted to mean that a larger portion of the congregation in the church had embraced worldliness and therefore were not committed to the worship of God while only a handful was committed. The group was meeting to pray about the vision and other spiritual matters that were necessary in uplifting the church and solving the challenges of the populace. It is important to note that the foundation of the society that was formed as a result of this fellowship was built upon prayer, fasting, devotion, and great zeal for Pentecostal manifestations. This was the focus and crave of the society that later blossomed into the Faith Tabernacle of Nigeria in 1923 (S.A. Fatokun, 2005).

A great proof of the possibility of spiritual manifestations among the group featured the same year. A woman known as Sophia Odúnlami (later Mrs. Àjayi) relayed her vision that God would heal people of their sicknesses if they could drink rainwater that God would send at a specific time. The bubonic epidemic, which was ragging then had claimed many lives and Nigeria was having its own share of this health crisis (Òshun, C.O. 2000, Ayégbóyìn, D. \& İshola, S. A. 1997, Olúshèye, E.H.L. 1994). After administering this curative portion, it was acclaimed that people became healed. This increased the hope of the people in the possibility and efficacy of divine healing through prayer and life of devotion to God. The founding fathers of the Precious Stone Society hinged their spirituality upon this basis and they were ready to uphold it with their might.

When the group began to swell in number and their conviction about devotion to prayer and emphasis on Divine Healing was becoming stronger, the mother church that housed them began to be apprehensive. At this time the name Precious Stone Society or Diamond Society (Egbe Okuta lyebiye) was given to the praying group (Ayégbóyin, D. and İshola, S. A. 1997, Peel, J.D.Y. 1968). This praying group was operating within the Anglican Church that housed them until when the relationship between the two could not continue. The reason for this was the claim of the group that the use of medicine for curing ailments was unbiblical and ungodly but rather by faith in the healing power of God. In addition, the group claimed that infant baptism was unbiblical and was the cause of the death of many infants in the church and this discomfited the church the more. They considered them as fanatics who were spreading false doctrines. As a result of this, the group could not be allowed to continue existing in the church while holding to and promoting their strange beliefs within the Anglican Church. The group was expelled from the Anglican Communion. The subsequent excommunication of the group could further be referred to as one of the initial causes for their affiliation with the Faith Tabernacle of Philadelphia, U.S.A. In essence, we are implying that the inability of Anglican Church, İjèbú-Òde to accommodate them for their rather strange Christianity led to their excommunication and the subsequent emergence of the Faith Tabernacle Church, Nigeria. Another reason for this emergence was the threat from the government (Oshun, C.O. 1985). The group affiliated with the Faith Tabernacle of Philadelphia to escape the hostilities of the colonial administration that frowned at any local spiritual movement operating independently.

While in association with the Faith Tabernacle of Philadelphia, they were not yet comfortable because the Faith Tabernacle Philadelphia did not believe in the conviction of the Nigerian group about Divine Healing without the use of drugs and medicine, either western or local. The group believed that their position on Divine Healing Cura Divina could 
be compromised by the rather lukewarm position of Philadelphia about healing (Òshun, C.O. 1981). After de-affiliating with the Faith Tabernacle of Philadelphia, they went into another affiliation with the Apostolic Church, Great Britain. They were seriously craving for the return of the experience, which these foreign groups trivialized. The foreign churches did not buy the local group's conviction about Divine Healing without the use of drugs and medicine, either western or local.

At this level, it is good to describe why divine healing was not popular around this time and why the foreign missions that Precious Stone Society affiliated with could not appreciate it. One of them was the Apostolic Church at Bradford. The position of the Bradford mission regarding Divine Healing was a product of its socio-cultural background. Europe, America and the Western world in general was a society that held to scientific research and the exploitation of its results for the improvement and advancement of human existence. A lot of unbeatable objectively demonstrated studies had been carried out in the field of medicine be it human or veterinary. Drugs capable of curing diverse illnesses, the most popular at the time being malaria fever provided medical remedies. Pharmacists and pharmacologists had discovered and were recommending anti-malaria drugs in clinics and hospitals. The circumstances in Nigeria then especially among the local people were the "reverse". The Yorùbá society and the Aladura Christians believed not as much of science and scientific researches. Somewhat they believed a great deal in the unprocessed administration of herbs, supernatural and divine healing.

The origin of illness or ill-fated occurrences is credited to malicious forces and powers such as witches, wizards, and sorcery. Other sources are associated with the precedential wicked actions and exploits of the victim, which occasioned retribution. This was the rationale behind the Aladura founders and Christians' conviction that the influenza epidemic and the depression which hit Yorùbáland between 1918, 1929 and 1931, were interpreted as the consequence of the sins of the Yorùbá Christians (Àyándélé E.A. 1981). Taking into consideration all these claims and explanations by the Aladura Christians for the cause of the epidemic, one would wonder why they had underemphasized the damages of the First World War and the consequential unpleasant outcome of the war on the countries of the world by and large and Southwestern Nigeria specially. All the socio-economic and health problems faced by the people then were regular problems associated with any country affected by war.

This disapproval led to break in relationship. Due to their association with the foreign churches, their doctrinal position on Divine Healing and Pentecostalism generally was penetrated and attempts were made to contaminate them (Oshun, C.O. 1981). However, the unflinching stand of the leaders about their conviction about Cura Divina held. The testimonies that followed the previous manifestations of the spiritual gifts among them were also sure stimulus that enhanced and energized their convictions to hold on to Cura Divina. However, the futility which the mergers brought and the dangers that they portended for the viability of the doctrine of Divine Healing (if continued) also constituted the reasons for their continual belief in divine healing.

It is necessary to mention that a man named Joseph Ayo Babalola was important towards the staging of a revival in 1930. This revival was generally acclaimed as a powerful evangelistic revival that became popular throughout West Africa. His strong conviction and sense of commitment towards Divine Healing further rekindled the inherent vigor of the adherents of Nigerian Faith Tabernacle. The 1930 Great Revival that ensued which recorded many miracles and healings also brightened the assurance that Divine Healing as a practice was possible. In addition, because many lives were touched positively during the revival, the assurance that Divine Healing was possible became more significant. Furthermore, the healings recorded showed that it was worth pursuing and defending.

The staunch members and leaders of the Faith Tabernacle realized the opposition that existed in the defunct Faith Tabernacle. Therefore, they decided to establish a church where their passion for renewed spirituality and expressive and more demonstrative Christianity could be freely expressed. Hence the birth of the African Indigenous Churches (AIC) was inevitable. The followings are some of the characteristics of the AIC's: stress on; prayer, the spiritual and Divine Healing. Others are that greater attention is accorded to women, fondness for freer form of worship, stress on African world-view, more devotion to evangelism and revival and absence of complex governmental structure (Ayégbóyìn, D. and İshola, S. A. 1997). The first AIC to be born in Southwestern Nigeria even though the founders of the church were not Faith Tabernacle members was the Cherubim and Seraphim Church in 1925. Since then AIC's have proliferated considerably throughout Southwestern Nigeria and the whole of Nigeria.

\section{Conclusion}

From the above mentioned it is obvious that the First World War dealt a great blow on the security of the entire world population. Africa as a continent shared from the problems in diverse ways. Its impact on Christianity in Southwestern Nigeria especially among the local people has been brought into view. It is our assumption that First World War was 
instrumental to the founding of charismatic/Pentecostal Christianity. It was a moment that Africans were able to discover their potentials and manifest them positively for the betterment of the continent. It was a moment when the Yoruba Christians started to repaint the African Christian picture in the light and passion of their people in contrast to what the foreign missionaries presented to them. It was also a moment when the people discovered properly that the fate of the Christianity they desired was already in their hands.

\section{Bibliography}

Agbeti, K.J. 1986. West African Church History: Christian Mission and Church Foundations 1842-1919. Leiden: E.J. Brill. 96.

Ayandele, E.A. 1966. The Missionary Impact on Modern Nigeria, 1842-1914, A Political and Social Analysis, London: Longman Group Ltd.

Ayégbóyìn, D. and İshola S. A. 1997. African indigenous churches: An historical perspective, Lagos: Greater Height Publications. 18.

Ethiopianism. (2010). Encyclopædia Britannica. Encyclopaedia Britannica Student and Home Edition. Chicago: Encyclopædia Britannica.

Fatokun, S.A. 2005. Pentecostalism in south-western Nigeria with emphasis on the Apostolic Church, 1931-2001, Ph.D Thesis Dept. of Religious Studies. University of İbàdàn. $x+100$.

Hasting, A. 1966. Church and mission in modern Africa. New York: Fordham University Press. 59.

Keylor, William R. 2009."World War I." Microsoft巴 Encarta® 2009 [DVD]. Redmond, WA: Microsoft Corporation, 2008.

Oduyoye. M. 1978. The Planting of Christianity in Yorubaland 1842-1888. O.U. Kalu Ed. Christianity in West Africa: The Nigerian Story. Ibadan: Daystar Press, 251.

Olúshèye, E.H.L. 1994. A short history of Christ Apostolic Church. İbàdàn: E.H.L Olúshèye Publications. 11.

Osshun, C.O. 1981. Christ Apostolic Church of Nigeria: a suggested pentecostal consideration of its historical, organizational and theological developments, 1918-1975. Ph.D Thesis. Exeter University. xvi+7 \& 8.

Òshun, C.O. 2000. Aladura revivals: Apostle Babalolá's challenge to Christian missions.Inaugural Lecture delivered at Lagos State University, Ojó on 26 July 2000. 11.

Peel, J.D.Y. 1968. The Aladura: A religious movement among the Yoruba. London: O.U.P. 48.

Webster. J.B. 1964. The African Church among the Yoruba. Oxford: Clarendon Press.

World War I. (2010). Encyclopædia Britannica. Encyclopaedia Britannica Student and Home

Edition. Chicago: Encyclopædia Britannica. 
